\author{
Iwona Wojciechowska-Toruńska \\ Instytut Nauk Społecznych \\ i Zarządzania Technologiami \\ Politechnika Łódzka
}

\title{
Polityka podatkowa a indeks szczęścia
}

\section{Streszczenie}

W artykule poruszono zagadnienie relacji polityki podatkowej i zadowolenia z życia. W celu dokonania przybliżonej analizy poziomu zadowolenia z życia w krajach o zróżnicowanej polityce podatkowej skonstruowano tzw. indeks szczęścia. Potwierdzono hipotezę, która brzmi: „Kraje o wysokim indeksie szczęścia nie muszą charakteryzować się wysokimi średnimi stawkami podatkowymi, ale powinny wyróżniać się progresją podatkową dochodu, wzrostem dywersyfikacji stawek podatkowych VAT oraz stabilnym poziomem wydatków publicznych w PKB". W poszukiwaniu optymalnej polityki podatkowej należy brać pod uwagę nie tylko tempo wzrostu gospodarczego, ale również tempo przyrostu społecznego zadowolenia czy poziom społecznego dobrostanu.

Słowa kluczowe: polityka podatkowa, wskaźniki rozwoju społeczno-ekonomicznego, ekonomia szczęścia, finanse publiczne.

\section{Wprowadzenie}

W ostatnich latach, kiedy kraje europejskie doświadczają niskiego wzrostu gospodarczego, Komisja Europejska zaleca reformę polityki podatkowej, która powinna skupić się nie tylko na efektywności ekonomicznej, ale przede wszystkim na ograniczaniu nierówności dochodowych [European Commission 2013c]. Jeżeli nierówności dochodowe wzrastają w relacji do przeciętnego wzrostu PKB na jednego mieszkańca, większość ludzi może być w gorszej sytu- 
acji finansowej, pomimo że przeciętny dochód narodowy rośnie [Stiglitz, Sen i Fitoussi 2009, s. 8]. Niektóre kraje, w tym Wielka Brytania, zaczęły obliczać relację szczęścia do PKB, aby monitorować rozwój gospodarczy narodu [Office for National Statistics 2013]. W raporcie Stiglitza znalazły się rekomendacje dotyczące badań poziomu życia obywateli [Stiglitz, Sen i Fitoussi 2009]. Unikatowym przykładem kraju, który opiera swoją strategię rozwoju społeczno-gospodarczego nie na ciągłym generowaniu wzrostu gospodarczego, ale na maksymalizacji wskaźnika szczęścia narodowego brutto (gross national happiness - GNH), jest Królestwo Bhutanu. GNH uwzględnia wiele aspektów funkcjonowania społeczeństwa, kultury, gospodarki, środowiska i państwa [Kołodko 2013, s. 398]. Z badań w wielu krajach wynika, że relacja między dochodem a zadowoleniem z życia jest pozytywna [Diener 1984, s. 553]. Subiektywne zadowolenie szczególnie wzrasta pod wpływem wzrostu dochodu w krajach biednych, a w krajach zamożnych nie zmienia się [Davis i Smith 2002]. W USA w ciągu 30 lat wartość PKB na jednego mieszkańca wzrosła dwukrotnie, a pomimo to nie zaobserwowano zwiększenia zadowolenia z życia wśród Amerykanów [Kołodko 2013, s. 386]. Wysoki poziom PKB nie musi zatem świadczyć o wzroście zadowolenia z życia w krajach bogatych. Jednocześnie kraje o wysokim PKB per capita najczęściej wyróżniają się wysokimi stawkami podatkowymi i niskim współczynnikiem nierówności dochodowych ${ }^{1}$. Obniżanie stawek podatkowych zalecane dla polityki podatkowej krajów unijnych wydaje się słuszne z perspektywy poprawy poziomu zadowolenia z życia [European Commission 2013a]. Niskie stawki podatkowe mogą też być korzystne dla wzrostu gospodarczego [Konopczyński 2012, s. 690]. Z przeglądu literatury finansów publicznych i ekonomii szczęścia wynika, że na wzrost poziomu zadowolenia podatników oprócz wysokości stawek podatkowych wpływa progresywna skala opodatkowania dochodów, wzrost dywersyfikacji opodatkowania konsumpcji oraz wielkość wydatków publicznych w relacji do PKB. Jeżeli dochody mają znaczenie dla zadowolenia z życia, a wielkość dochodów rozporządzalnych zależy od wysokości stawek podatkowych, to można sądzić, że niskim średnim stawkom podatkowym w krajach biednych może towarzyszyć równie wysoki wskaźnik zadowolenia z życia jak w krajach bogatych o wysokich średnich stawkach podatkowych, gdyż z powodu niskich stawek podatkowych wzrastają dochody rozporządzalne. Postawiono następującą hipotezę: Kraje o wysokim wskaźniku zadowolenia z życia nie muszą charakteryzować się wysokimi średnimi stawkami podatkowymi, ale powinny wyróżniać się progresją podatkową, wzrostem dywersyfikacji stawek podatkowych VAT oraz stabilnym poziomem wydatków publicznych w PKB. Potwierdzenie tej hipotezy może być odpowiedzią na kierunek zmian w polityce podatkowej

\footnotetext{
${ }^{1}$ W krajach skandynawskich współczynnik Giniego wynosi około $20 \%$ i świadczy o równym rozkładzie dochodu społeczeństwa [Orłowski 2010, s. 158].
} 
w krajach UE mających zachodzić w najbliższym czasie. Celem artykułu jest przedstawienie relacji polityki podatkowej i zadowolenia z życia. Należy jednak pamiętać, że instrumenty polityki fiskalnej, które oddziałują pozytywnie na rozwarstwienie materialne społeczeństwa, mogą wpływać negatywnie na wzrost gospodarczy, i odwrotnie [Ostaszewski 2010, s. 256]. Przykładem są wydatki publiczne ${ }^{2}$, które są zdecydowanie negatywnie skorelowane ze wzrostem gospodarczym [Cotis 2005].

Zadowolenie z życia zostało w niniejszym artykule przeanalizowane z wykorzystaniem wskaźników dobrobytu społecznego, takich jak:

- indeks rozwoju społeczno-ekonomicznego HDI (human development index), który od 2010 r. ocenia kraje, wykorzystując oczekiwaną długość życia, średnią liczbę lat edukacji mieszkańców w wieku 25 lat i starszych, oczekiwaną liczbę lat edukacji dzieci rozpoczynających proces kształcenia, dochód narodowy per capita w USD, liczony według parytetu nabywczego waluty;

- indeks jakości życia QLI (quality of life index), który mierzy dodatkowo bezpieczeństwo (stopa morderstw, gwałtów), stan rodziny i przyjaźni (stopa rozwodów), warunki pracy, migracje itd., a także PKB na jednego mieszkańca, bezrobocie, nierówność rozkładu dochodów, ubóstwo. Wskaźnik został opracowany w 2005 r. przez brytyjski tygodnik „The Economist” dla odzwierciedlenia poziomu życia i satysfakcji życiowej w poszczególnych krajach w bardziej adekwatny sposób tradycyjnymi metodami (jak wskaźniki wzrostu PKB lub poziom PKB na mieszkańca);

- PKB per capita.

W celu dokonania przybliżonej analizy poziomu zadowolenia z życia w krajach o zróżnicowanej polityce podatkowej skonstruowano tzw. indeks szczęścia (IS), który jest średnią arytmetyczną wskazanych indeksów. Wszystkie indeksy zostały znormalizowane za pomocą unitaryzacji. Pojęcie zadowolenia z życia jest $w$ artykule stosowane zamiennie z pojęciem indeksu szczęścia.

Metody badawcze zastosowane w opracowaniu to parametryczny opis szeregu szczegółowego z użyciem miar średnich oraz wielokryterialna metoda rangowania (zob. [Stabryła 2000]). W pierwszej metodzie wykorzystano jedną z najczęściej stosowanych miar średnich, jaką jest średnia arytmetyczna. Drugiej metodzie towarzyszy porządkowanie preferencyjne. Formułę obliczenia indeksu szczęścia przedstawiono w punkcie 2 artykułu.

${ }^{2}$ Zespół OECD zaobserwował, że wśród wydatków publicznych tylko konsumpcja i inwestycje rządowe wykazują dodatnią zależność z produkcją per capita [Cotis 2005]. 


\section{Instrumenty podatkowe i zadowolenie z życia}

Różnorodne badania relacji opodatkowania i zadowolenia z życia czy subiektywnego poczucia szczęścia mogą być drogowskazem zmian w polityce podatkowej. Dobrobyt społeczny zależy od funkcji redystrybucyjnej państwa ${ }^{3}$. Jeżeli celem systemu podatkowego jest maksymalizacja indywidualnego dobrobytu, skala opodatkowania dochodów społeczeństwa powinna być progresywna. Progresywne opodatkowanie zmniejsza nierówności społeczne [Bankman i Griffith 1987, s. 1967]. S. Oishi, wykorzystując dane Global Gallup Poll, zbadał wpływ opodatkowania progresywnego na poczucie zadowolenia podatników [Oishi, Schimmack i Diener 2011]. Okazało się, że relacja ta jest pozytywna. Polskie badania potwierdzają tezę, że progresja podatkowa w podatkach dochodowych zmniejsza stopień nierówności społecznych, a w podatkach konsumpcyjnych tak samo pozytywnie oddziałuje wzrost dywersyfikacji opodatkowania [Walasik 1998, s. 122]. Wpływ na nierówności społeczne mają także inne rodzaje podatków, przedstawione w tabeli 1 jako szczególne faktory korygujące.

Tabela 1. Wpływ poszczególnych instrumentów podatkowych mechanizmu politycznego na współczynnik nierówności podziału dochodu w społeczeństwie

\begin{tabular}{|l|l|l|}
\hline \multicolumn{1}{|c|}{ Faktor } & \multicolumn{1}{|c|}{ Instrument polityki podatkowej } & \multicolumn{1}{|c|}{$\begin{array}{c}\text { Wpływ na stopień } \\
\text { nierówności }\end{array}$} \\
\hline \multirow{3}{*}{ Majątkowy } & wzrost stawki podatku majątkowego & zmniejszenie \\
\cline { 2 - 3 } & zerowa stawka podatku majątkowego & bez wpływu \\
\cline { 2 - 3 } & spadek stawki podatku majątkowego & zwiększenie \\
\hline \multirow{3}{*}{ Dochodowy } & progresywne opodatkowanie dochodów & zmniejszenie \\
\cline { 2 - 3 } & proporcjonalne opodatkowanie dochodów & bez wpływu \\
\cline { 2 - 3 } & regresywne opodatkowanie dochodów & zwiększenie \\
\hline Konsumpcyjny & $\begin{array}{l}\text { wzrost dywersyfikacji opodatkowania konsumpcji } \\
\text { - represyjny charakter podatków akcyzowych }\end{array}$ & zmniejszenie \\
\cline { 2 - 3 } & jednolite stawki opodatkowania konsumpcji & bez wpływu \\
\cline { 2 - 4 } & spadek dywersyfikacji opodatkowania konsumpcji & zwiększenie \\
\hline
\end{tabular}

Źródło: [Walasik 1998, s. 122].

Ludzie, którzy korzystają z dóbr publicznych, takich jak transport publiczny czy edukacja, odczuwają subiektywne zadowolenie. Płacenie podatków w ramach opodatkowania progresywnego ma pozytywny wpływ na zado-

\footnotetext{
${ }^{3}$ Struktura podatku powinna redystrybuować dochód od bogatych do biednych [Bankman i Griffith 1987].
} 
wolenie z życia, gdyż kojarzone jest z możliwością korzystania z usług i dóbr publicznych. Podobne do wyników A. Walasika rezultaty badań osiągnęli B.S. Frey, S. Luechinger i A. Stutzer [2009], S. Luechinger [2009], S. Luechinger i P.A. Raschky [2009]. Podatki są głównym źródłem przychodów w sektorze finansów publicznych, dlatego wyższe stawki podatkowe prowadzą do przeciętnie wyższej konsumpcji dóbr publicznych ${ }^{4}$. Osoby przynajmniej raz w miesiącu korzystające z publicznych usług kulturalnych są bardziej zadowolone niż te, które z nich nie korzystają [Siegloch i in. 2012]. Wysokie podatki najczęściej odpowiadają wysokiej konsumpcji dóbr publicznych, wysokiemu zadowoleniu i niskim nierównościom dochodowym, ale są niekorzystne dla wzrostu gospodarczego [Angelopoulos, Economides i Kammas 2007, Lee i Gordon 2005]. Polityka podatkowa poprzez zróżnicowanie stawek podatkowych i tytułów podatkowych może oddziaływać na stopień nierówności rozkładu bogactwa w społeczeństwie. $\mathrm{W}$ poszukiwaniu optymalnych stawek podatkowych z perspektywy zadowolenia z życia czy dobrobytu społecznego rozważano także wiek. Uważa się, że najniższe stawki podatkowe powinny dotyczyć osób młodych [Kremer 1997] 5 . Na podstawie przeglądu literatury można stwierdzić, że wpływ na zadowolenie z życia mają następujące czynniki: wysokość i rodzaj stawki podatkowej, rodzaj podatku, wzrost dywersyfikacji opodatkowania w podatkach konsumpcyjnych, wielkość wydatków publicznych oraz wiek podatnika.

\section{Analiza relacji wysokości, rodzaju i dywersyfikacji stawek podatkowych oraz indeksu szczęścia w krajach Europy w latach 1995-2012}

W badaniu relacji wysokości, rodzaju i dywersyfikacji stawek podatkowych oraz wskaźnika zadowolenia z życia uwzględniono 28 krajów UE i Norwegię. Spośród tej grupy krajów wyselekcjonowano dwie grupy krajów: o najwyższej i najniższej średniej stawce podatkowej ${ }^{6}$. Mediana średnich stawek podatkowych dla lat 1995-2012 wyniosła 30,27. Kraje o wysokiej stawce podatkowej to te, w których jest ona wyższa od mediany, a ich średnia stawka podatkowa to $33,71 \%$. Kraje o niskiej stawce podatkowej to kraje, w których jej wartość jest

${ }^{4}$ Grupa ekonomistów OECD potwierdziła wyniki uzyskane we wcześniejszych publikacjach, że duże obciążenia podatkowe wpływają negatywnie na poziom PKB per capita [Cotis 2005].

${ }^{5}$ Literatura odnosząca się do szczęścia wskazuje, że ludzie w średnim wieku są ogólnie najmniej szczęśliwi spośród różnych grup wiekowych [Kremer 1997].

${ }^{6}$ Średnia stawka podatkowa została wyliczona jako średnia arytmetyczna uwzględniająca średnie stawki podatkowe w trzech głównych podatkach: PIT, CIT i VAT w latach 1995-2012 na podstawie danych Eurostatu [European Commission 2013b]. 
poniżej mediany. Średnia stawka podatkowa w krajach o niskich średnich stawkach podatkowych wyniosła $25,03 \%$. Metodą rankingową ustalono pozycje krajów w poszczególnych grupach. Kolejnym krokiem w badaniu była analiza krajów o najwyższym indeksie szczęścia (wskaźniku zadowolenia z życia) w swoich grupach ze względu na występowanie progresji podatkowej i dywersyfikacji stawek VAT. Dodatkowo dla potwierdzenia rangi (pozycji) indeksu szczęścia wykorzystano współczynnik nierówności rozkładu dochodu Giniego ${ }^{7}$ oraz wielkość wydatków publicznych w relacji do $\mathrm{PKB}^{8}$. Metoda rankingowa pomaga ustalić pozycje krajów o wysokich i niskich średnich stawkach podatkowych ze względu na wielkość indeksu szczęścia. Każdy kraj ma przypisaną rangę od 1 do $5 \mathrm{w}$ odpowiedniej kategorii. Ranga najwyższa to 1, a najniższa to 5 . Wskaźnik zadowolenia z życia $\left(Z_{i}\right)$, tzw. indeks szczęścia, jest średnią arytmetyczną trzech indeksów: indeksu rozwoju społeczno-ekonomicznego HDI, indeksu jakości życia OLI i PKB per capita. Wszystkie indeksy znormalizowano za pomocą unitaryzacji tak, że najlepsza odnotowana wartość w ramach każdego indeksu wynosi 1. Maksymalna wartość indeksu szczęścia to 1, a najniższa to 0. Można to przedstawić w postaci następującej formuły:

$$
Z_{i}=\frac{P K B_{i}+H D I_{i}+Q L I_{i}}{3},
$$

gdzie:

$Z_{i}$ - wskaźnik zadowolenia z życia (od 0 do 1 ) w $i$-tym roku,

$P K B_{i}$ - zunitaryzowany indeks PKB per capita $\mathrm{w} i$-tym roku, roku,

$H D I_{i}$ - zunitaryzowany indeks rozwoju społeczno-ekonomicznego w $i$-tym

$Q L I_{i}$ - zunitaryzowany indeks jakości życia w $i$-tym roku.

W tabeli 2 przedstawiono zestawienie krajów europejskich o najwyższych średnich stawkach podatkowych oraz wskaźniki dobrobytu społecznego. Średnia stawka podatkowa to średnia arytmetyczna stawek w podatkach dochodowych i w podatku pośrednim od towarów i usług, jakim jest popularny VAT, w latach 1995-2012.

\footnotetext{
${ }^{7}$ Wartość współczynnika informuje o nierównościach dochodowych. Jego wartość zmienia się od 0 (doskonała równość) do 1 (zupełna nierówność). Im wyższa wartość tego współczynnika, tym większe nierówności dochodowe, np. w krajach skandynawskich osiąga on wartość około 0,20 (co świadczy o bardzo równym rozkładzie dochodów), a w krajach rozwijających się jego wartość wynosi w granicach 0,60-0,70 (co oznacza skrajnie nierówny podział dochodów) [Czarny 2011, s. 309].

${ }^{8}$ Wydatki publiczne są negatywnie skorelowane ze wzrostem gospodarczym, a pozytywnie wpływają na rozwarstwienie materialne społeczeństwa [Ostaszewski 2010, s. 256].
} 
Tabela 2. Najwyższe średnie stawki podatkowe w krajach UE i w Norwegii w latach 1995-2012 i znormalizowane indeksy dobrobytu społecznego w 2012 r.

\begin{tabular}{|c|l|c|c|c|c|c|c|c|}
\hline $\begin{array}{c}\text { Ranga } \\
\text { podat- } \\
\text { kowa }\end{array}$ & Kraj & $\begin{array}{c}\text { Średnia stawka } \\
\text { podatkowa } \\
\text { w latach } \\
1995-2013(\%)\end{array}$ & HDI & $\begin{array}{c}H D I_{i} \\
\text { dla } \\
i=2012\end{array}$ & $\begin{array}{c}P K B_{i} \\
\text { (tys. USD) } \\
\text { dla } \\
i=2012\end{array}$ & $\begin{array}{c}\text { PKB } \\
\text { per capita } \\
2012\end{array}$ & QLI & $\begin{array}{c}Q L I_{i} \\
\text { dla } \\
i=2012\end{array}$ \\
\hline 1 & Dania & 39,6 & 0,901 & 0,69 & 32,1 & 0,53 & 163,1 & 0,86 \\
\hline 2 & Belgia & 39,4 & 0,897 & 0,66 & 30,7 & 0,50 & 100,68 & 0,45 \\
\hline 3 & Niemcy & 36,6 & 0,920 & 0,80 & 31,5 & 0,52 & 184,42 & 1,00 \\
\hline 4 & Holandia & 36,1 & 0,921 & 0,80 & 32,6 & 0,55 & 158,07 & 0,83 \\
\hline 5 & Norwegia & 35,3 & 0,955 & 1 & 49,6 & 1,00 & 168,41 & 0,90 \\
\hline
\end{tabular}

Źródło: opracowanie własne na podstawie danych Eurostatu [European Commission 2013b]; www. pordata.pt, dostęp: 25.03.2014.

Tabela 3. Indeks szczęścia $\left(Z_{i}\right)$ w grupie krajów europejskich o najwyższej średniej stawce podatkowej w 2012 r. i ich ranking

\begin{tabular}{|l|c|c|c|}
\hline \multicolumn{1}{|c|}{ Kraj } & $\begin{array}{c}\text { Średnia stawka podatkowa w latach } \\
\text { 1995-2012(\%) }\end{array}$ & $Z_{2012}$ & Ranking \\
\hline Dania & 39,6 & 0,693 & 4 \\
\hline Belgia & 39,4 & 0,539 & 5 \\
\hline Niemcy & 36,6 & 0,772 & 2 \\
\hline Holandia & 36,1 & 0.727 & 3 \\
\hline Norwegia & 35,3 & 0,965 & 1 \\
\hline
\end{tabular}

Źródło: opracowanie własne na podstawie tabeli 2 i formuły (1).

Tabela 4. Kraje UE o najniższej średniej stawce podatkowej i znormalizowane indeksy dobrobytu społecznego w tych krajach w 2012 r.

\begin{tabular}{|c|l|c|c|c|c|c|c|c|}
\hline $\begin{array}{c}\text { Ranga } \\
\text { podat- } \\
\text { kowa }\end{array}$ & Kraj & $\begin{array}{c}\text { Średnia stawka } \\
\text { podatkowa w latach } \\
1995-2012(\%)\end{array}$ & HDI & $\begin{array}{c}H D I_{i} \\
\text { dla } \\
i=2012\end{array}$ & $\begin{array}{c}\text { PKB per } \\
\text { capita } \\
\text { (tys. USD) }\end{array}$ & $P K B_{i}$ & QLI & $\begin{array}{c}Q L I_{i} \\
\text { dla } \\
i=2012\end{array}$ \\
\hline 1 & Łotwa & 20,9 & 0,814 & 0,18 & 16,4 & 0,12 & 86,39 & 0,36 \\
\hline 2 & Litwa & 21,65 & 0,818 & 0,21 & 18,3 & 0,17 & 114,05 & 0,54 \\
\hline 3 & Estonia & 22,20 & 0,846 & 0,37 & 18,2 & 0,16 & 145,4 & 0,75 \\
\hline 4 & Bułgaria & 23,08 & 0,782 & 0,00 & 12 & 0,00 & 30,77 & 0,00 \\
\hline 5 & Czechy & 23,43 & 0,873 & 0,53 & 20,7 & 0,23 & 88,14 & 0,37 \\
\hline
\end{tabular}

Źródło: opracowanie własne na podstawie danych Eurostatu [European Commission 2013b], www. pordata.pt, dostęp: 25.03.2014, www.numbeo.com, dostęp: 25.03.2014. 
Tabela 5. Indeks szczęścia w krajach UE o najniższej średniej stawce podatkowej i ich ranking

\begin{tabular}{|l|c|c|c|}
\hline \multicolumn{1}{|c|}{ Kraj } & $\begin{array}{c}\text { Średnia stawka podatkowa w latach } \\
1995-2012\end{array}$ & $Z_{2012}$ & Ranking \\
\hline Łotwa & 20,9 & 0,221 & 4 \\
\hline Litwa & 21,65 & 0,306 & 3 \\
\hline Estonia & 22,20 & 0,427 & 1 \\
\hline Bułgaria & 23,08 & 0,000 & 5 \\
\hline Czechy & 23,43 & 0,377 & 2 \\
\hline
\end{tabular}

Źródło: opracowanie własne na podstawie tabeli 4 i formuły (1).

Wykorzystując formułę (1), można stwierdzić, że w krajach o najwyższych średnich stawkach podatkowych poziom zadowolenia z życia jest ogólnie wysoki. Jednak maksymalnej średniej stawce podatkowej $(39,6 \%)$ występującej w Danii nie towarzyszy najwyższy poziom zadowolenia z życia wśród krajów o najwyższych stawkach podatkowych. Norwegia wyróżnia się najwyższym poziomem zadowolenia z życia i najniższą średnią stawką podatkową $(35,3 \%)$ w tej grupie krajów. Można sądzić, że im niższe średnie stawki podatkowe, tym wyższy poziom zadowolenia z życia, jednak średnia stawka podatkowa nie powinna być niższa niż $35,3 \%$. W tabeli 4 zestawiono najniższe średnie stawki podatkowe w krajach UE i wskaźniki dobrobytu społecznego.

Wśród krajów o najniższych średnich stawkach podatkowych indeks szczęścia jest zróżnicowany. Bułgaria jest krajem, w którym wskaźnik ten jest najniższy. Estonia to kraj o najwyższym wskaźniku zadowolenia z życia w grupie krajów o najniższych stawkach podatkowych. Zadziwiający jest fakt, że te dwa kraje mają bardzo podobną średnią stawkę podatkową, a wskaźnik zadowolenia z życia w Bułgarii wynosi zero. Niskie zadowolenie z życia w Bułgarii ma potwierdzenie we wskaźniku Giniego, który wynosił w Bułgarii w 2012 r. 33,6\%, ale w Estonii był niewiele niższy (tylko o 1,1 p.p.) i wynosił 32,5\%. Te dwa kraje o podobnych średnich stawkach podatkowych i podobnym wskaźniku Giniego stosowały jeden próg podatkowy (podatek proporcjonalny) w PIT, podobnie jak inne kraje o najniższych średnich stawkach podatkowych. Jednak w Estonii progi podstawowych preferencji podatkowych wzrastały od 2003 r., co oznaczało, że średnia stawka podatkowa od dochodu osobistego rosła wraz z osiąganym dochodem [European Commission 2013b, s. 74]. Dlatego uważa się, że podatek dochodowy od osób fizycznych w Estonii jest progresywny, choć stawka wynosi $21 \%$ od 2008 r. Bułgaria od 2008 r. ma podatek liniowy PIT o stawce 10\%; wcześniej stosowała progresję podatkową z trzema progami [European Commission 2013b, s. 60]. W pozostałych krajach o najniższych średnich stawkach podatkowych brak 
progresji podatkowej. Z kolei wśród krajów o najwyższych średnich stawkach podatkowych obserwuje się kilka progów podatkowych w PIT, np. w Belgii jest ich 7, w Holandii 4, a w Niemczech 3. Można sądzić, że niska średnia stawka podatkowa nie jest wystarczającym czynnikiem powodującym podwyższenie indeksu szczęścia. Kraje, które stosują progresję podatkową o co najmniej trzech progach podatkowych, mają wyższy poziom różnych wskaźników dobrobytu społecznego niż kraje, które progresji nie stosują. Czechy i Estonia to kraje o najwyższym indeksie szczęścia wśród krajów o najniższych średnich stawkach podatkowych. W grupie krajów o najwyższej średniej stawce podatkowej wskaźnik zadowolenia z życia jest najwyższy w Norwegii, Niemczech i Holandii.

Przyjrzyjmy się teraz relacjom współczynnika Giniego oraz wydatków publicznych w krajach o najniższych i najwyższych średnich stawkach podatkowych, które jednocześnie w swoich grupach charakteryzowały się najwyższymi indeksami szczęścia.

Tabela 6. Współczynnik Giniego i wydatki publiczne w krajach o najniższych i najwyższych średnich stawkach podatkowych i najwyższych wskaźnikach zadowolenia w swoich grupach

\begin{tabular}{|l|c|c|c|c|c|c|}
\hline \multirow{2}{*}{ Kraj } & \multicolumn{2}{|c|}{$\begin{array}{c}\text { Współczynnik Giniego } \\
\text { (GI, \%) }\end{array}$} & $\begin{array}{c}\text { Zmiana } \\
\text { GI }\end{array}$ & \multicolumn{2}{c|}{$\begin{array}{c}\text { Wydatki publiczne } \\
\text { (WP, \% PKB) }\end{array}$} & $\begin{array}{c}\text { Zmiana } \\
\text { WP }\end{array}$ \\
\cline { 2 - 7 } & 2005 & 2012 & $2005-2012$ & 2005 & 2012 & $2005-2012$ \\
\hline Czechy & 26 & 24,9 & $-1,1$ & 43 & 44,5 & $+1,5$ \\
\hline Estonia & 34,1 & 32,5 & $-1,6$ & 33,6 & 39,5 & $+5,9$ \\
\hline Niemcy & 24,1 & 28,3 & $+4,2$ & 46,9 & 44,7 & $-2,2$ \\
\hline Holandia & 26,9 & 25,4 & $-1,5$ & 44,8 & 50,4 & $+5,6$ \\
\hline
\end{tabular}

Zródło: Eurostat, http://ec.europa.eu/eurostat/web/government-finance-statistics/overview, dostęp: 25.03.2014 i www.pordata.pt, dostęp: 25.03.2014.

W latach 2005-2012 nierówności społeczne w Estonii, w Holandii i w Czechach zmalały o odpowiednio 1,6 p.p., 1,5 p.p., 1,1 p.p. W tym samym czasie wydatki publiczne w tych państwach wzrosły odpowiednio o 5,9 p.p. PKB, 5,6 p.p. PKB i 1,5 p.p. PKB. W Niemczech w latach 2005-2012 nierówności społeczne wzrosły, gdyż zmalały wydatki publiczne, jednak nadal jest to kraj o relatywnie niskim współczynniku Giniego. Estonia i Niemcy nie charakteryzują się podobnym poziomem nierówności społecznych i ich średnie stawki podatkowe bardzo się różnią. W Estonii ze średnią stawką podatkową 22,2\% indeks szczęścia wynosi 0,427 . Niemcy, o średniej stawce podatkowej 36,6\%, mają prawie dwa razy wyższy wskaźnik zadowolenia z życia niż Estonia - wynosi on 0,772 . Z kolei Belgia, która ma średnią stawkę podatkową wyższą od estońskiej aż o 17,4 p.p., ma tylko o 11,2 p.p. wyższy indeks szczęścia. Można stwierdzić, że wskaźnik ten 
może być na podobnym poziomie w krajach o wysokich i niskich stawkach podatkowych. Kolejnym ważnym czynnikiem oprócz progresji podatkowej mogącym wpływać na standard życia społecznego jest wzrost dywersyfikacji stawek w podatkach konsumpcyjnych. W Estonii stawka podstawowa VAT wzrosła z 18\% do $20 \%$ w 2009 r. [European Commission 2013b, s. 67], a stawka obniżona w tym samym roku wzrosła z 5\% do 9\%. W Czechach stawka podstawowa VAT wzrosła z 17\% w 2012 r. do 18\% w 2013 r. [European Commission 2013b, s. 67], przy zachowaniu pozostałych obniżonych stawek: $8 \%$ i 5\%. W Holandii stawka podstawowa VAT wzrosła już w 2012 r. do 21\% z 19\% w 2011 r. [European Commission 2013b, s. 124]. W Niemczech podstawowa stawka VAT wzrosła z 17\% do 19\%, a obniżona pozostała bez zmian od 2009 r. i wynosi 7\%. Wzrost dywersyfikacji stawek podatku od towarów i usług w Holandii w Estonii i w Czechach sprzyja zmniejszaniu się współczynnika nierówności społecznych. W krajach, w których wzrosły wydatki publiczne, zmalały nierówności społeczne, a w krajach, w których zmalały wydatki publiczne, było odwrotnie. Zaobserwowano, że tempo wzrostu wydatków publicznych jest szybsze niż tempo redukcji współczynnika nierówności dochodowych.

\section{Podsumowanie}

Podatki jako instrument polityki fiskalnej mogą być ważnym czynnikiem kształtującym poziom zadowolenia z życia obywateli. Z przeglądu literatury wynika, że do czynników mających wpływ na zadowolenie z życia zalicza się: wysokość i rodzaj stawki podatkowej, wzrost dywersyfikacji stawek podatkowych w podatkach konsumpcyjnych oraz wielkość wydatków publicznych w relacji do PKB. Progresja podatkowa powinna uwzględniać wiek podatnika. Po analizie wpływu wybranych instrumentów podatkowych na tzw. indeks szczęścia można stwierdzić, że rodzaj i dywersyfikacja stawek podatkowych mają większe znaczenie dla tego wskaźnika niż wysokość średnich stawek podatkowych. Przypadek Estonii świadczy o tym, że niskim stawkom podatkowym może towarzyszyć prawie taki sam indeks szczęścia jak w krajach o wysokich stawkach podatkowych. Można sądzić, że w krajach, w których występuje progresywne opodatkowanie dochodów, powinien być niski stopień nierówności społecznych i tym samym wysokie zadowolenie z życia. Zaobserwowano, że w krajach, w których progresja podatkowa opierała się co najmniej na trzech progach podatkowych, indeks szczęścia był wyższy niż w tych, w których progresja była ograniczona. W badanych krajach wzrost dywersyfikacji stawek w podatku od towarów i usług miał korzystny wpływ na nierówności społeczne. W krajach o wysokim indeksie szczęścia poziom wydatków publicznych był stabilny. Tempo wzrostu wydatków 
publicznych było szybsze niż tempo redukcji nierówności społecznych. Postawiona we wstępie hipoteza: „Kraje o wysokim wskaźniku zadowolenia z życia nie muszą charakteryzować się wysokimi średnimi stawkami podatkowymi, ale powinny wyróżniać się progresją podatkową, wzrostem dywersyfikacji stawek podatkowych VAT oraz stabilnym poziomem wydatków publicznych w PKB" została potwierdzona.

Progresja podatkowa o co najmniej trzech progach podatkowych oraz wzrost dywersyfikacji stawek w podatku od towarów i usług mogą mieć istotne znaczenie dla kształtowania polityki podatkowej opartej na zrównoważonym wzroście społecznym. Stabilny poziom wydatków publicznych jest korzystny dla ograniczenia nierówności społecznych. W poszukiwaniu optymalnej polityki podatkowej należy brać pod uwagę nie tylko tempo wzrostu gospodarczego, ale również tempo przyrostu społecznego zadowolenia czy poziom społecznego dobrostanu. Wnioski te mogą być cenną wskazówką dla polskiej polityki podatkowej.

\section{Literatura}

Angelopoulos K., Economides G., Kammas P. [2007], Tax-spending Policies and Economic Growth: Theoretical Predictions and Evidence from the OECD, „European Journal of Political Economy", nr 23(4), http://dx.doi.org/10.1016/j.ejpoleco.2006.10.001.

Bankman J., Griffith T. [1987], Social Welfare and the Rate Structure: A New Look at Progressive Taxation, „California Law Review”, vol. 75, nr 6.

Cotis J.P. [2005], Zrozumieć wzrost gospodarczy. Analiza na poziomie makroekonomicznym, poziomie branży i poziomie firmy, Oficyna Ekonomiczna, Kraków.

Czarny B. [2011], Podstawy ekonomii, PWE, Warszawa.

Davis J., Smith T. [2002], General Social Surveys, National Opinion Research Center, Chicago.

Diener E. [1984], Subjective Well-being, „Psychological Bulletin”, vol. 95, nr 3.

European Commission [2013a], Recent Reforms of Tax Systems in the EU: Good and Bad News, Brussels.

European Commission [2013b], Taxation Trends in the European Union. Data for the EU Member States, Iceland and Norway, Eurostat Statistical Book, Brussels.

European Commission [2013c], Tax Reforms in EU Member States 2013, Working Papers no 38, Brussels.

Eurostat / National Entities - European Community Household Panel (ECHP), European Statistics on Income and Living Conditions (EU-SILC) [2014], http://ec.europa.eu/ geninfo/legal_notices_en.htm, dostęp: 27.03.2014.

Frey B.S., Luechinger S., Stutzer A. [2009], The Life Satisfaction Approach to Valuing Public Goods: The Case of Terrorism, „Public Choice”, vol. 138, nr 3-4, http://dx.doi.org/ 10.1007/s11127-008-9361-3.

Kołodko G.W. [2013], Dokad zmierza świat. Ekonomia polityczna przyszłości, Prószyński i S-ka, Warszawa.

Konopczyński M. [2012], Wpływ opodatkowania na wzrost gospodarczy, „Ekonomista”, nr 6. 
Kremer M. [1997], Should Taxes be Independent of Age, NBER Working Papers no 6304.

Luechinger S. [2009], Valuing Air Quality Using the Life Satisfaction Approach, „The Economic Journal”, vol. 119(536), http://dx.doi.org/10.1111/j.1468-0297.2008.02241.x.

Luechinger S., Raschky P.A. [2009], Valuing Flood Disasters Using the Life Satisfaction Approach, ,Journal of Public Economics”, vol. 93(3-4), http://dx.doi.org/10.1016/j.jpubeco.2008.10.003.

Pordata, publiczny serwis danych statystycznych dla Portugalii oraz krajów UE, www. pordata.pt, dostęp: 25.03.2014.

Office for National Statistics [2013], Personal Well-being in the UK, 2012/2013, Statistical Bulletin, 30 July 2013, http://www.ons.gov.uk/ons/dcp171778_319478.pdf, dostęp: 20.02.2013.

Oishi S., Schimmack U., Diener E. [2011], Progressive Taxation and the Subjective Well-being of Nation, ,Psychological Science”, vol. 23(1), http://pss.sagepub.com/content/23/1/86 (dostęp: 5.03.2014), http://dx.doi.org/10.1177/0956797611420882.

Orłowski W.M. [2010], W pogoni za straconym czasem. Wzrost gospodarczy w Europie Środkowo-Wschodniej 1950-2030, Polskie Wydawnictwo Ekonomiczne, Warszawa.

Ostaszewski J. [2010], Finanse, Difin, Warszawa.

Siegloch S. i in. [2012], Income, Taxes and Happiness, IZA, Bonn 2012.

Stabryła A. [2000], Zarzadzanie strategiczne w teorii i praktyce firmy, PWN, Warszawa.

Stiglitz J.E., Sen A. Fitoussi J.P. [2009], Report by the Commission on the Measurement of Economic Performance and Social Progress, Commission on the Measurement of Economic Performance and Social Progress, General Assembly of the United Nations, Paris.

Walasik A. [1998], Polityczny mechanizm podziału dochodu w społeczeństwie, Ruch Prawniczy, Ekonomiczny i Socjologiczny, z. 2.

\section{Tax Policy and the Happiness Index}

The article addresses the relationship between taxation and satisfaction with life. What is known as a happiness index was constructed to perform an approximate analysis of the level of life satisfaction in countries with different tax policies. The hypothesis, which states, 'Countries with a high happiness index need not have high average tax rates but should be identifiable by their progressive income tax, increased diversification of VAT rates and stable level of public expenditure as a proportion of GDP' was verified positively. The search for the optimal tax policy should take into account not only economic growth but also the growth rate of social satisfaction and the level of social welfare.

Keywords: tax policy, indicators of socio-economic development, the economics of happiness, public finance. 